\title{
Enemy on the Walls: A Preliminary Report of the Throwing Remains on the Hellenistic Acropolis of Kastritsa (Epirus, NW Greece)
}

\author{
Dimitris Kontogiorgos, Hara Kappa \\ Ephoria of Antquities, Ministry of Culture and Sports, Ioannina, Greek \\ Email: mitsaraskonto@hotmail.com
}

How to cite this paper: Kontogiorgos, D., \& Kappa, H. (2020). Enemy on the Walls: A Preliminary Report of the Throwing Remains on the Hellenistic Acropolis of Kastritsa (Epirus, NW Greece). Archaeological Discovery, 8, 188-198.

https://doi.org/10.4236/ad.2020.82010

Received: March 25, 2020

Accepted: April 11, 2020

Published: April 14, 2020

Copyright (c) 2020 by author(s) and Scientific Research Publishing Inc. This work is licensed under the Creative Commons Attribution International License (CC BY 4.0).

http://creativecommons.org/licenses/by/4.0/

\begin{abstract}
In this paper we present the artillery remains of a military conflict (i.e., mainly arrowheads) assumed to be related to the resistance of the Hellenistic city of Kastritsa in inland Epirus (NW Greece) during the last year of the Third Macedonian War (168 B.C). New archaeological evidence allowed us to link the Hellenistic city of Kastritsa to the ancient city of Tekmon mentioned by Livy.
\end{abstract}

\section{Keywords}

Throwing(s), Hellenistic Battle Field, Arrow Heads, Tekmon, Kastritsa, Epirus (NW Greece)

\section{Introduction}

In Chapter 26 of Book 45 (Livy 45.26) of his monumental work on the history of Rome, Titus Livius (1905) describes the course of Roman General Lefkius Anikius in the summer of $168 \mathrm{BC}$ from Illyria to the south, after his overwhelming victory over the king of Illyria Genthios in Skodra (now in Albania). This march resulted in the conquest of Epirus (Figure 1) by the Romans, and the subsequent destruction of its settlements, paying dearly their philo-Macedonian policy during the Third Macedonian War (171-168 B.C). Livy's text is as follows:

Leaving Illyria, Lefkius Anikius invaded Epirus (Praepositis his Illyrico, reliquo exercitu in Epirum est profectus), with the city of Fanoti as his first station, which was delivered without a fight and the inhabitants rushed to welcome him (Ubi prima Phanote ei dedita est omiii multitudine cum infulis obviam effusa). Then, upon his arrival in Molossia, the general installed guards in most Molossian cities (apparently not meeting resistance), with the exception of four Passarona, 


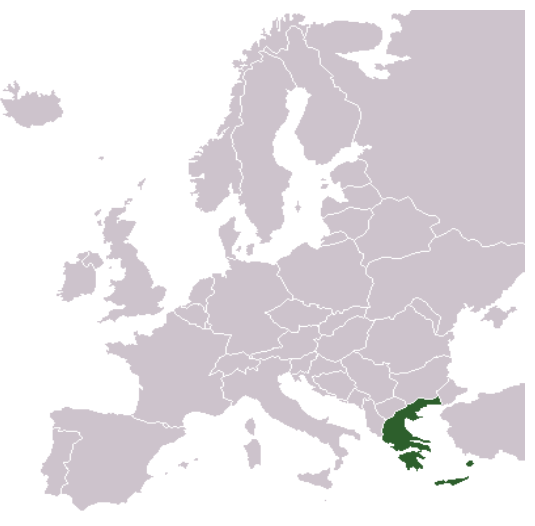

(a)

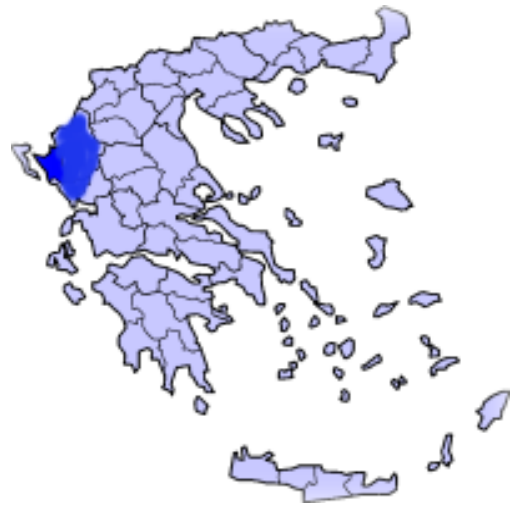

(b)

Figure 1. (a) Map of Europe showing the location of Greece; (b) Map of Greece showing the location of Epirus (Source: Wikipedia).

Tekmona, Fylaki and Orraon (Hinc praesidio imposito in Molossidem transgressus, cuius omnibus oppidis praeter Passaronem et Tecmonem et Phylacen et Horreum receptis primum ad Passaronem ducit).

From the text of the Roman historian we learn that the inhabitants of Passarona, despite the pressure of resistance by its two leaders, Antinous and Theodotus, chose to open the gates of the city and surrender to the Romans, with the two leaders falling dead in defense of their own decision to resist, not hoping anyway for the leniency of Rome (Haec dicentem cum multitude sequeretur, Antinous et Theodotus in primam stationem hostium inruperunt atque ibi offerentes se ipsi volneribus interfecti; urbs dedita est Romanis). The same perseverance and resistance were demonstrated by Kefalos, the leader of Tekmon, until his death in battle, when the city finally surrendered (Simili pertinacia Cephali principis clausum Tecmonem ipso interfecto per deditionem recepit). Neither Fylaki nor Orraon resisted the siege (Nec Phylace nee Horreum oppugnationem tulerunt).

The historian's references to the events of 168 B.C that marked the history of Epirus are not particularly detailed. Thus, the uncertainty of the sources and the unsafe identification of the settlements constitute a difficult pursuit for restoring the specific historical events (e.g., Cabanes, P. \& Andreou, J., 1985: pp. 520-521; Dausse, M. P., 2007: pp. 197-233). Then again, the documentation of the destruction of the Epirotic settlements by the Romans, has been the subject of archaeological excavations of various sites in modern research, focusing mostly on identifying and dating the so-called "layers of destruction" (i.e. in situ preserved burnt and/or unburnt occupation layers) (e.g., Pliakou, G., 2014). However, modern research provides a milder picture of what was until recently believed as a widespread destruction and desolation, revealing partial recovery of the settlements (e.g., Karatzeni, V., 2001: pp. 163-179).

Therefore, a significant desideratum is the archaeological documentation of the war conflicts of the specific historical period (i.e., 168 B.C). The preservation and retrieval of such archaeological layers is rare, either due to their being overrun by subsequent occupation layers or because of the lack of targeted excavation sections. However, the archeological research in Epirus has occasionally 
identified preserved material remains and/or stratigraphic evidence that is directly related to-or could be linked-to warfare (e.g., Dakaris, S., 1964: p. 50; Baatz, D., 1982; Andreou, J., 1997: p. 28, Figure 4 and Figure 5; Gravani, K. \& Katsikoudis, N., 2019). And yet, recent excavation at the Hellenistic acropolis of Kastritsa (Epirus-NW Greece) not only revealed vast evidence for a war conflict plausibly related with the Roman invasion in Epirus (i.e., 168/167 B.C) but also put a line of argument on the question regarding the identification of specific archaeological sites in Epirus successively linking the city once expanded inside the city walls of the Hellenistic acropolis of Kastritsa to the historic city of Tekmon mentioned by Livy.

\section{Location}

The Hellenistic city of Kastritsa is situated on a hill rising steeply on the southern outskirts of Lake Pamvotis, close to the modern city of Ioannina. The location fulfilled all the prerequisites for the foundation of a fortified city, offering a good site cover to the southern half of the Ioannina basin; good control of the two main road axes passing through its foothills; immediate access to the lake's aquatic and fertile habitat, and at the same time, offered a natural protection on its two steep sides (east and north) (Figure 2).

\section{Unearthing the Archaeological Evidence of a War Conflict on the Hellenistic Acropolis of Kastritsa}

Recent archaeological work on the Hellenistic Acropolis of Kastritsa has focused, inter alia, on the southern part of the fortification, and in particular, on its eastern projection, supported by two (2) towers, a quadrilateral and a triangular. According to the preliminary study of the fortification, the initial quadrilateral tower was strengthened by a strong triangular addition, which extended the projection of the tower by 17 meters (Figure 3, Figure 4) (Kappa, H. \& Kontogiorgos, D., 2018). The excavation immediately in front of the triangle tower

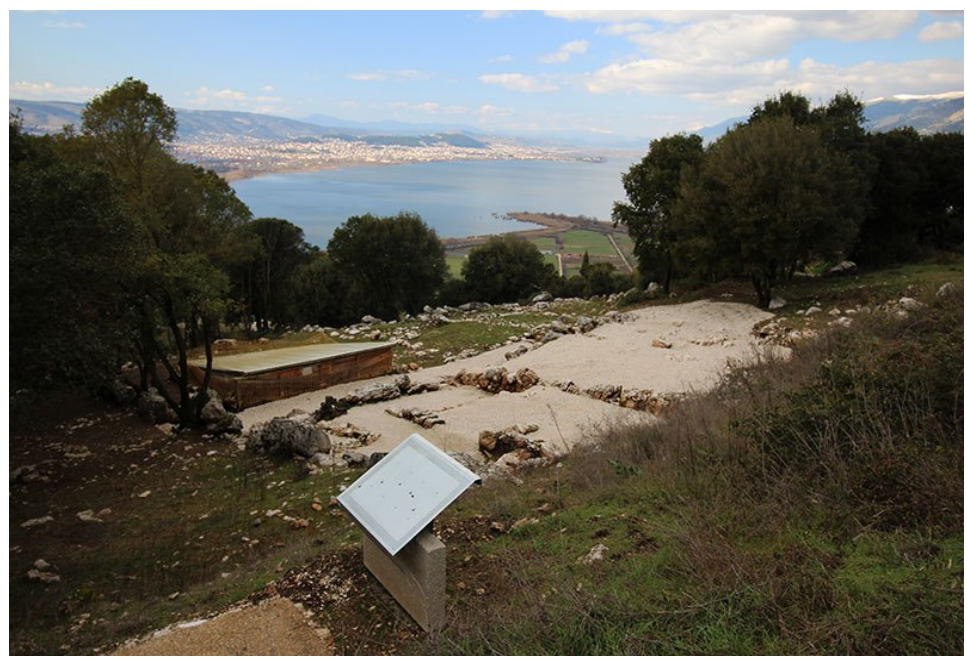

Figure 2. View of the modern city of Ioannina from the site. 


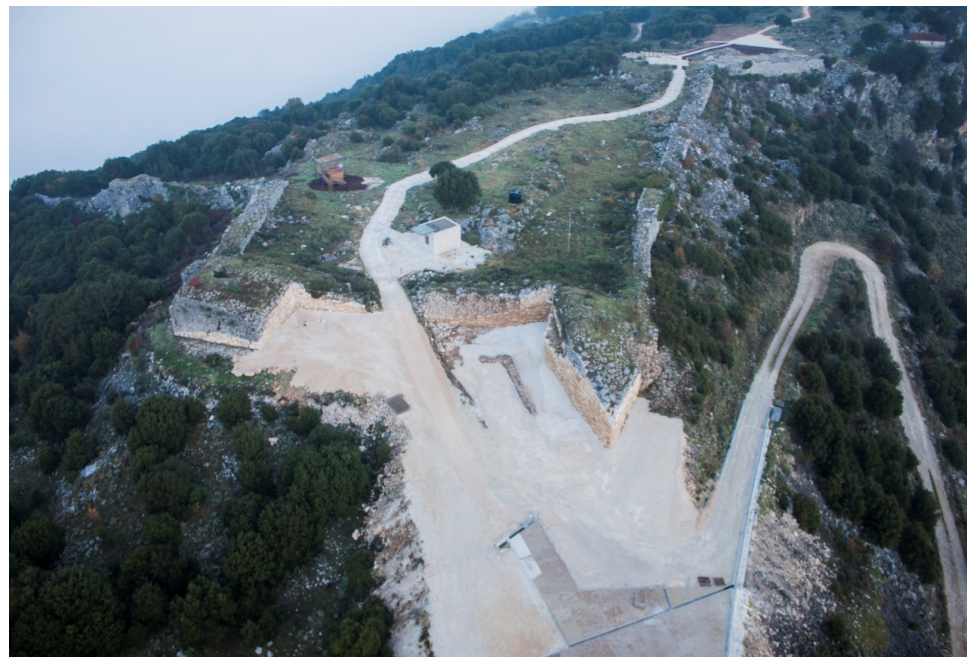

Figure 3. Aerial view of the eastern projection of the fortification.

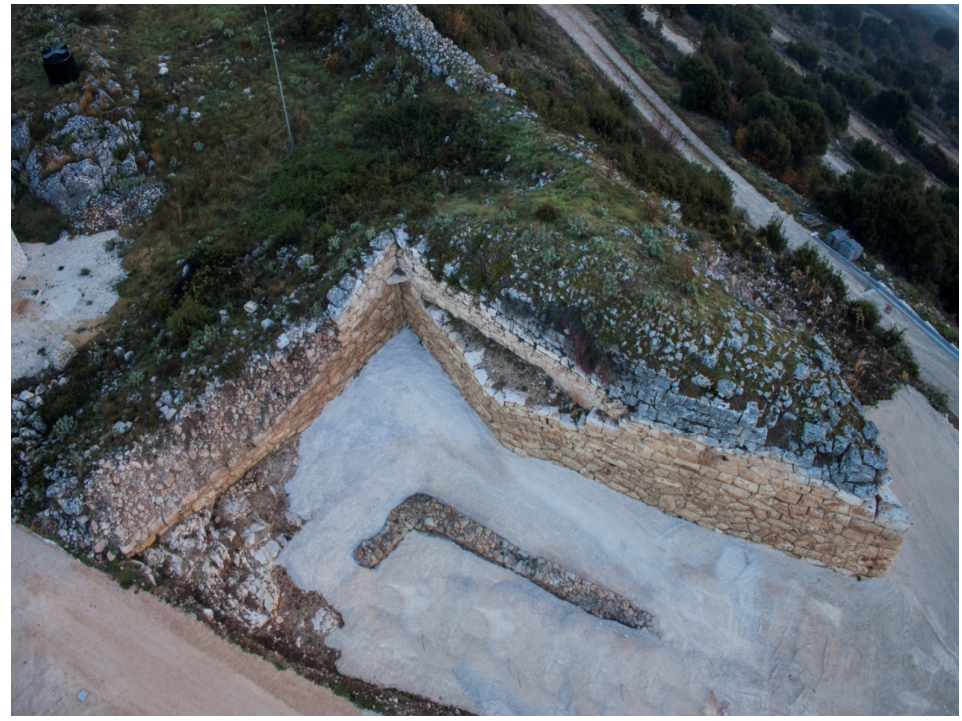

Figure 4. Aerial view of the triangular tower.

unveiled an undisturbed "layer of battle" that intactly retains the remains of a war clash outside the city walls. The concentration of iron objects in the Kastritsa "battle layer" contained at least 50 iron arrowheads, 2 round stone projectiles, some iron nails, an iron chain, and two hooks. The iron arrowheads were largely of a pyramid-shape and only a few were triangular with hooked back ends and an elongated stem for nesting of the wooden posts. According to studies, the spearheads with a flute and pyramid-shaped peak with four sides are characterized as catapult arrow heads (e.g., Baatz, D. \& Feugère, M., 1981: pp. 201-210, pp. 208-209, Figure 13).

The length of the arrowheads ranges between $7 \mathrm{~cm}$ to $13 \mathrm{~cm}$ and weighing between c.a. 27 and c.a.155 grams. Thirty (30) arrowheads from the Kastritsa "battle layer" were preliminary studied and grouped, according to weight, in four (4) main categories (Figure 5, Figure 6) (e.g., Baatz, D., 1982: pp. 229-231). 

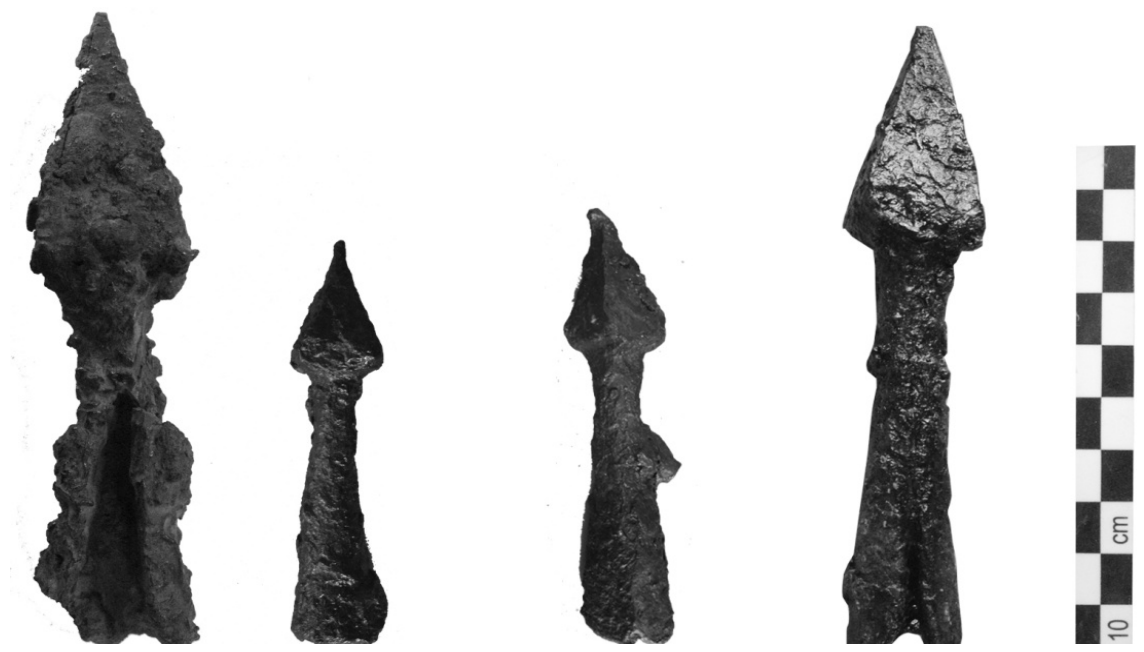

Figure 5. The four (4) main categories of arrowheads according to weight (from left to right: category I, IV, III, II).

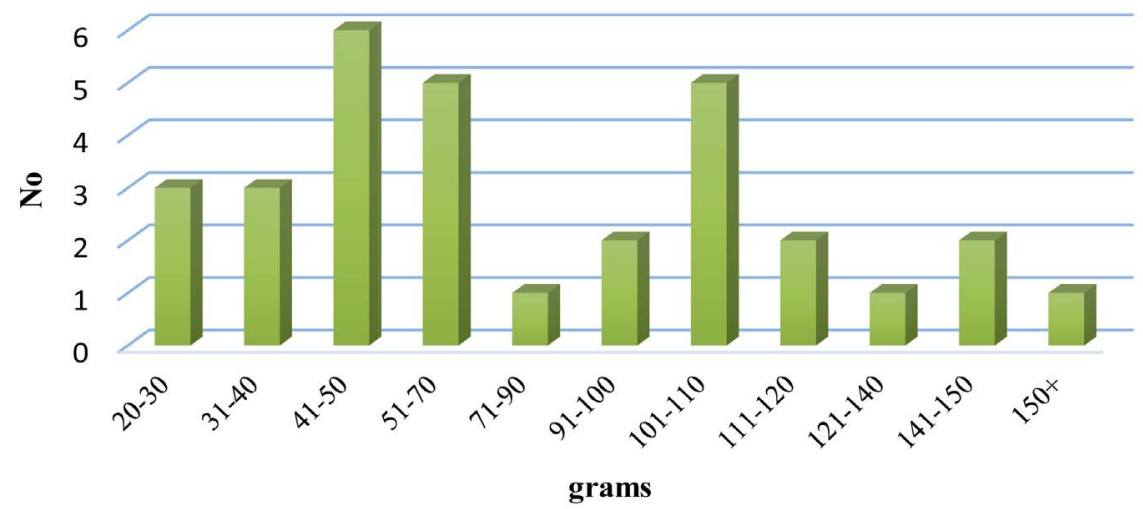

Figure 6. Comparative table displaying the numbers of arrowheads vs weight.

At least twelve (12) arrows were discerned exhibiting a long, heavy peak, ranging in length between $4 \mathrm{~cm}$ to $5 \mathrm{~cm}$, and weighing more than 100 grams (category I); one (1) arrowhead weighted approximately155 grams (category II). Moreover, ten (10) arrow heads weigh between 40 and 50 grams and the peak length varies roughly between $2 \mathrm{~cm}$ and $3 \mathrm{~cm}$ (category III) while only three (3) weigh less than 30 grams (category IV) (Figures 7-14).

Despite the deformation of the arrowheads due to the high corrosion of the iron, a subsistent correspondence was detected between the total weight of the arrowhead and the lower diameter of the lumen, ranging between $12 \mathrm{~mm}$ (for arrowheads weighing between 25 and 30 grams) to $2 \mathrm{~cm}$ (for arrowheads weighing more than 100 grams); the lower inner diameter of the lumen of the heaviest arrow head (i.e., c.a. 155 grams) is c.a. $2.5 \mathrm{~cm}$. Thus, the different characteristics of the Kastritsa arrowheads strongly point towards different catapult sizes depending on the size and weight of the projectile (e.g., Hacker, B. C., 1968: pp. 34-50; Baatz, D., 1978: pp. 1-17; Campbell, D. B., 2011: pp. 677-700). As for the stone missiles, their weight (4.60 and $6.3 \mathrm{~kg}$ ) corresponds to 10 and 15 mina respectively, according to Filon's table (Figure 15) (e.g., Baatz, D., 1982: p. 223). 


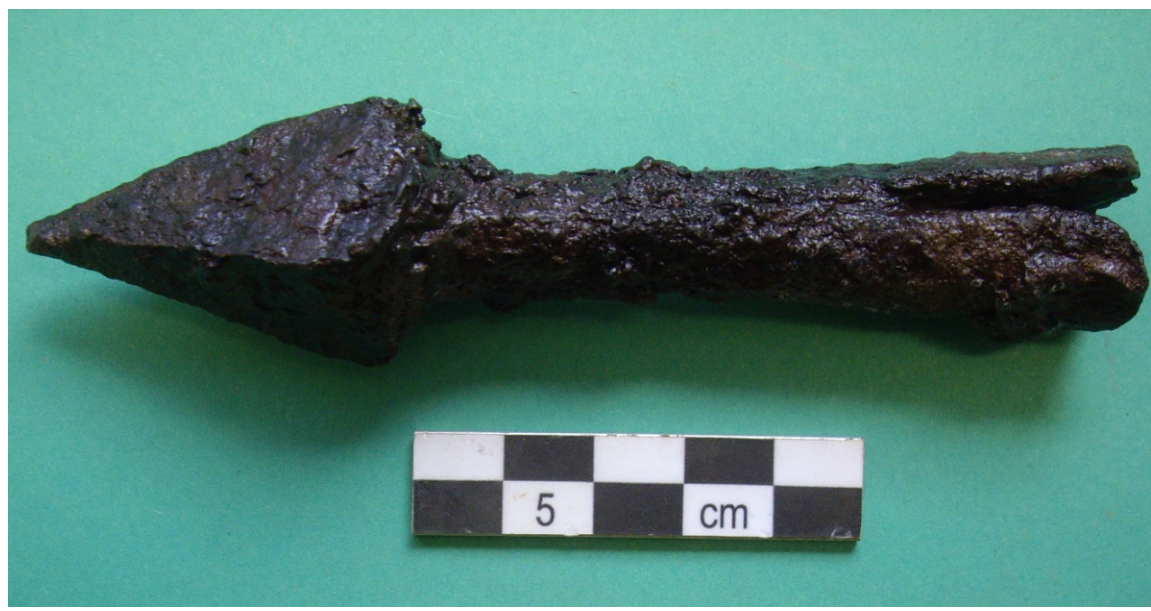

Figure 7. Arrowhead from Kastritsa (category II).

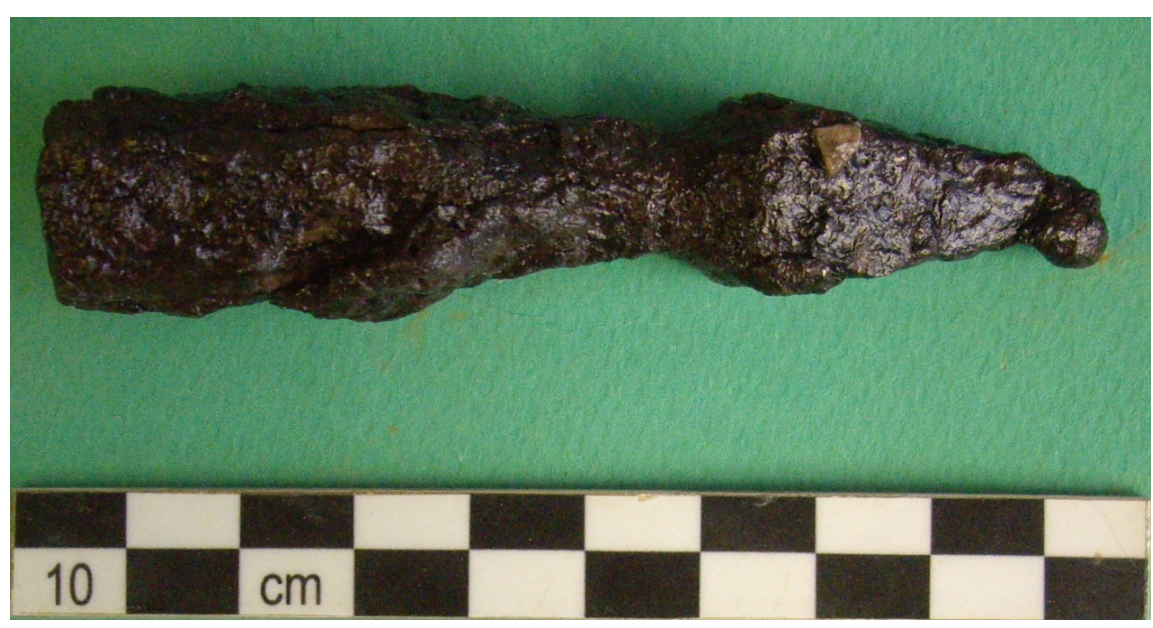

Figure 8. Arrowhead from Kastritsa (category I).

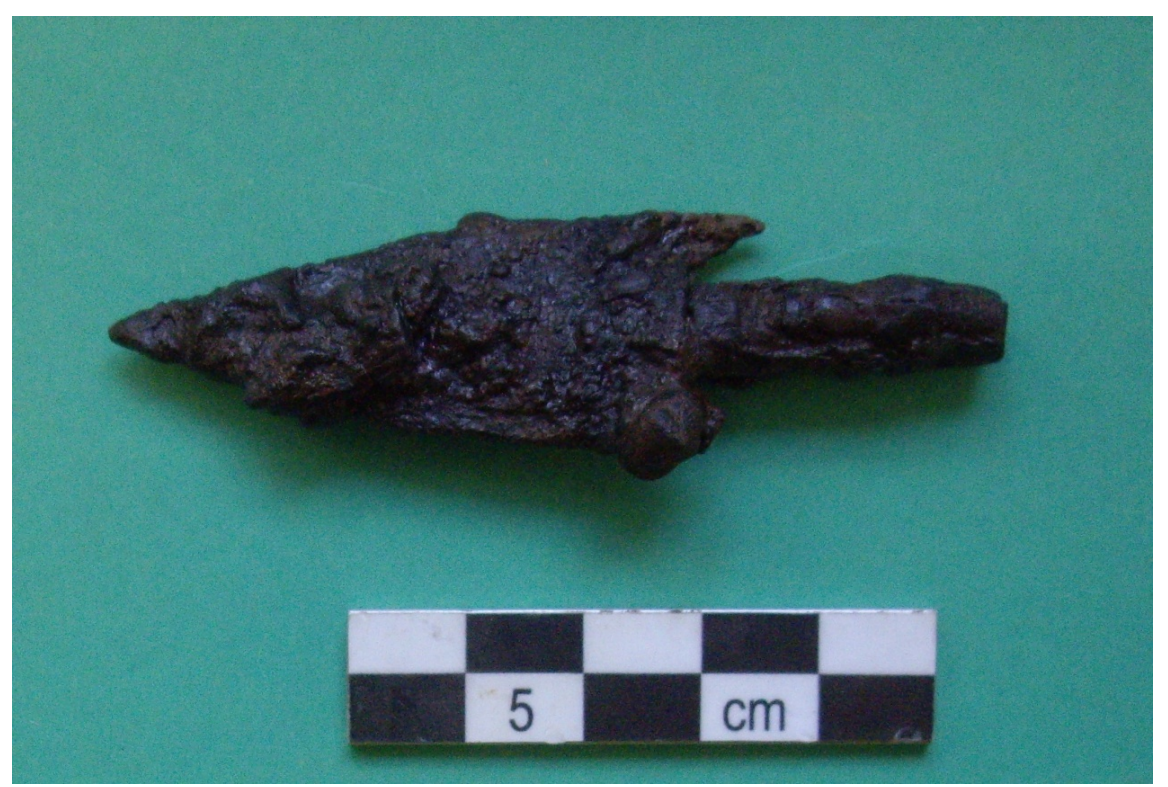

Figure 9. Arrowhead from Kastritsa (category III). 


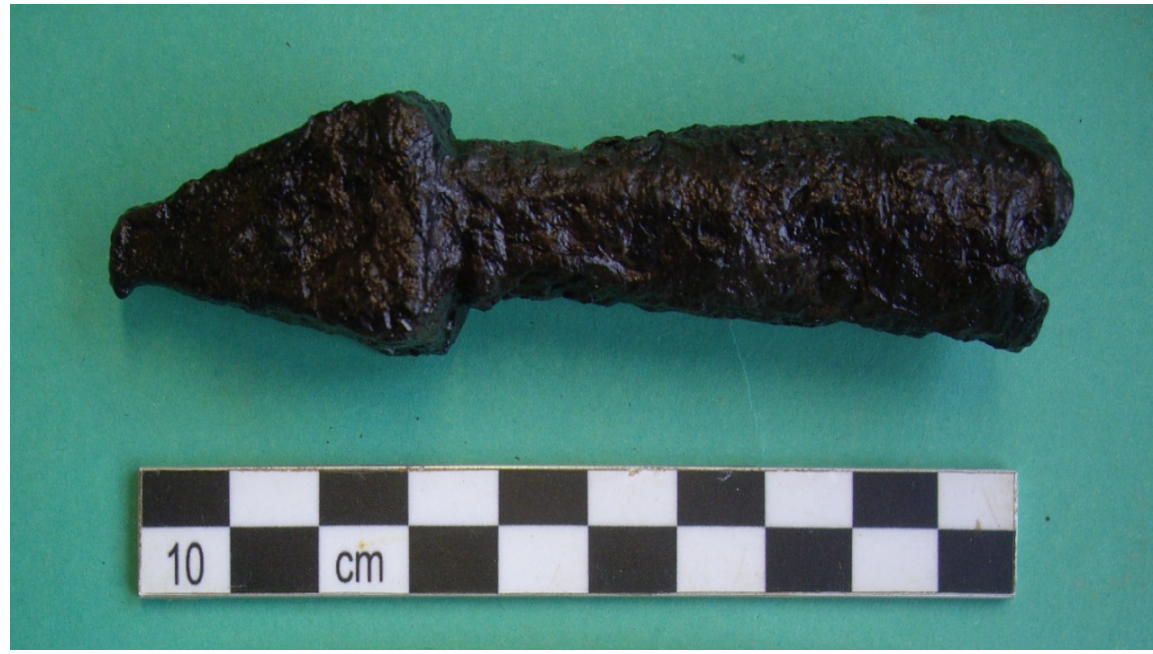

Figure 10. Arrowhead from Kastritsa (category I).

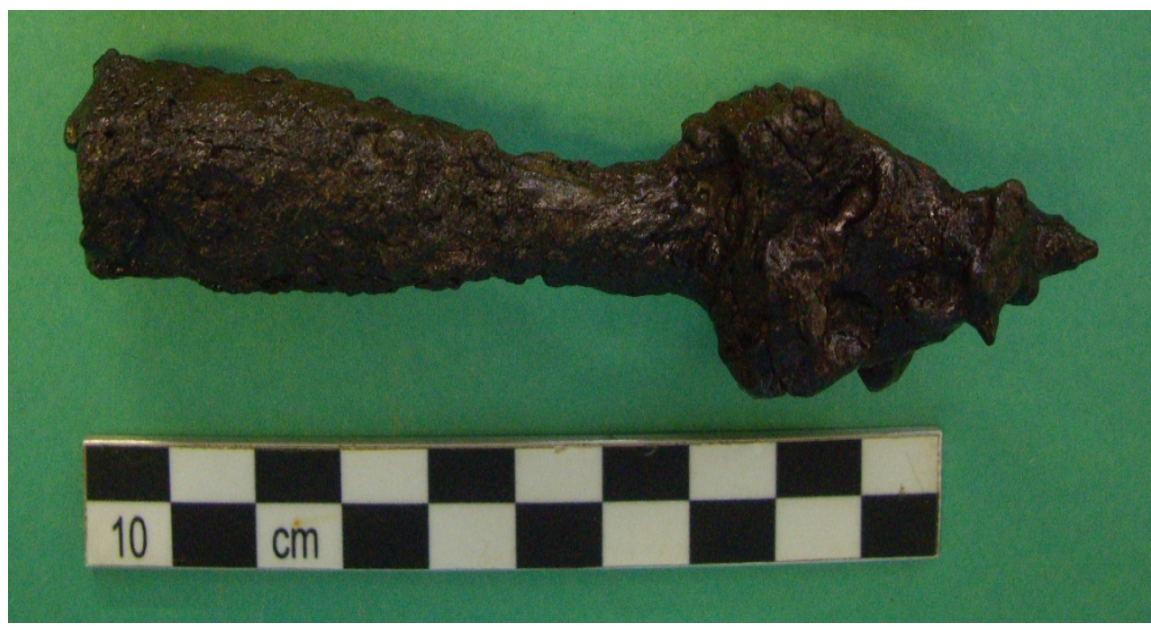

Figure 11. Arrowhead from Kastritsa (category I).

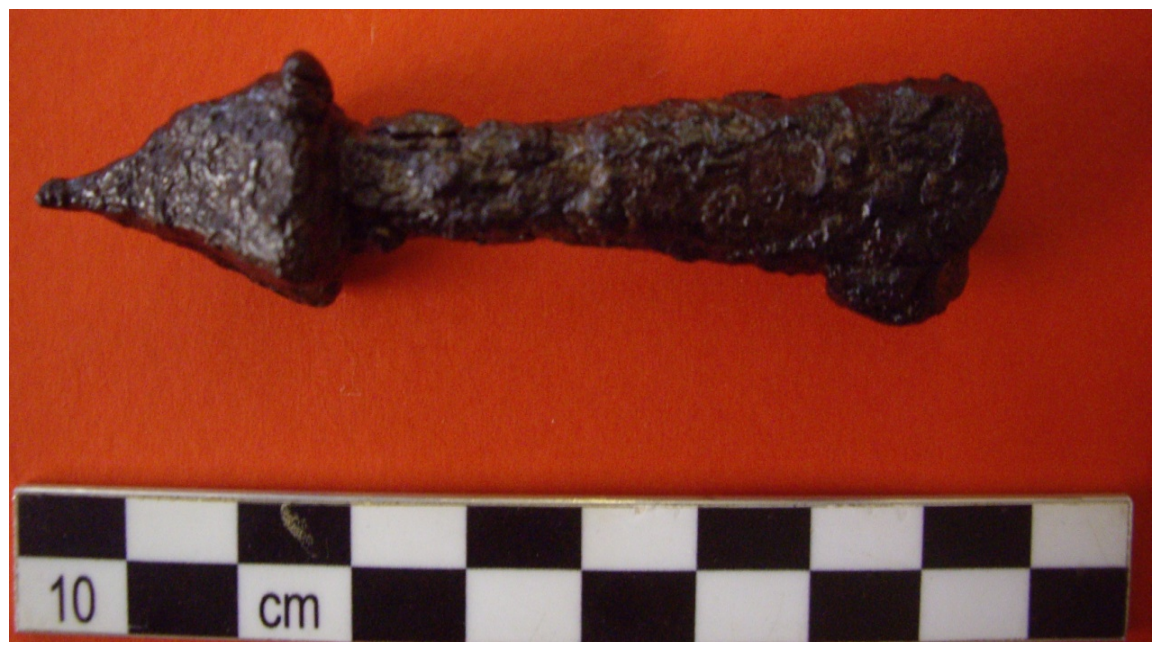

Figure 12. Arrowhead from Kastritsa (category I). 


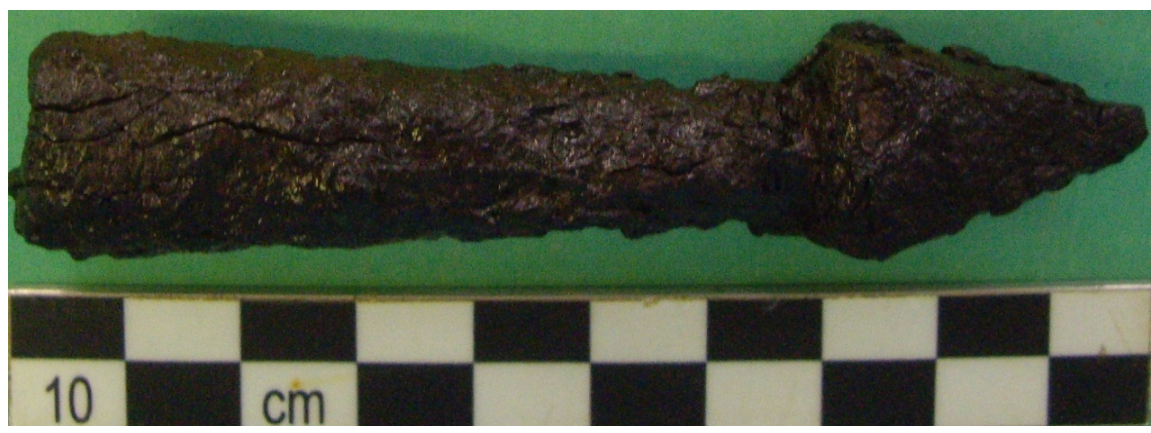

Figure 13. Arrowhead from Kastritsa (category I).

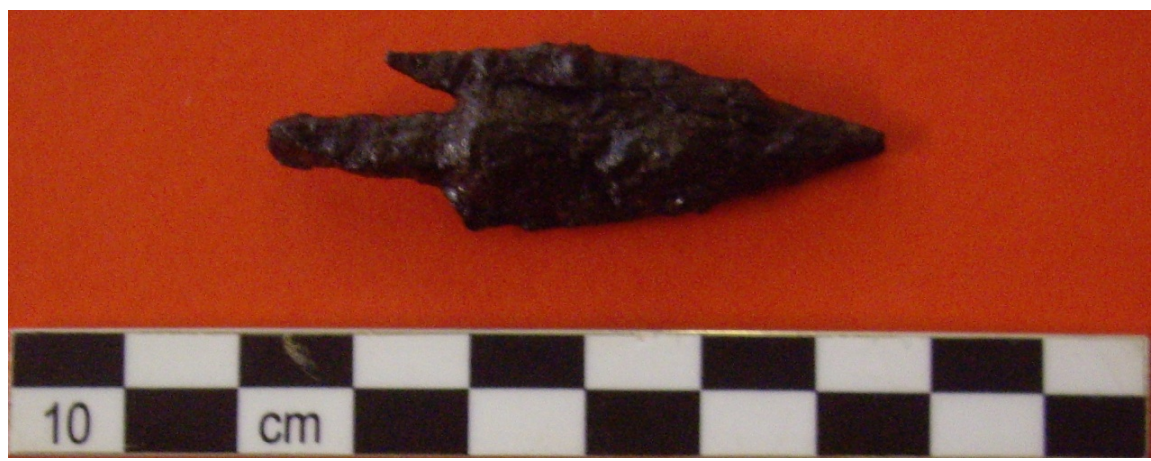

Figure 14. Arrowhead from Kastritsa (category IV).

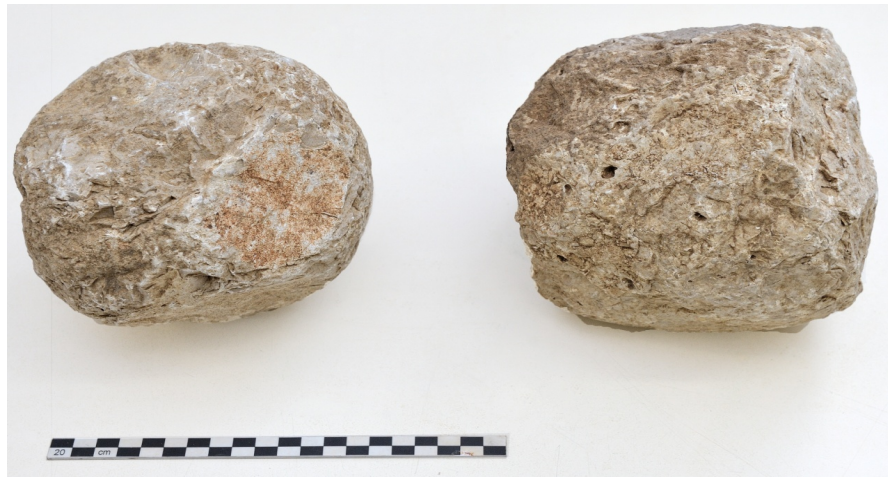

Figure 15. Stone missiles from Kastritsa.

One question that arises is whether the missiles (iron and stone) come from the siege engines of the besieger or whether they are defensive missiles. Then again, the in situ detection of the arrowheads pointing towards the fortification wall and the distortions of the edges of the peaks might provide an indication, although by no means conclusive, of the remnants of the besieger's throwings. Additional evidence in favor of the siege and the resistance of the fortified Hellenistic city on the hill of Kastritsa are the detection, after excavation, of temporary masonry foundations, adjacent to the edge of the tower (Figure 16 and Figure 17). It is worth noting that the fortification of the Hellenistic city is intersected with the opposite hill (i.e., where the potential camping and attacking point of the enemy army might have been-although not yet confirmed by archaeological data) by a steep rocky cliff at least 200 meters long and ca $50 \mathrm{~m}$ deep preventing from direct attack (Figure 18). 


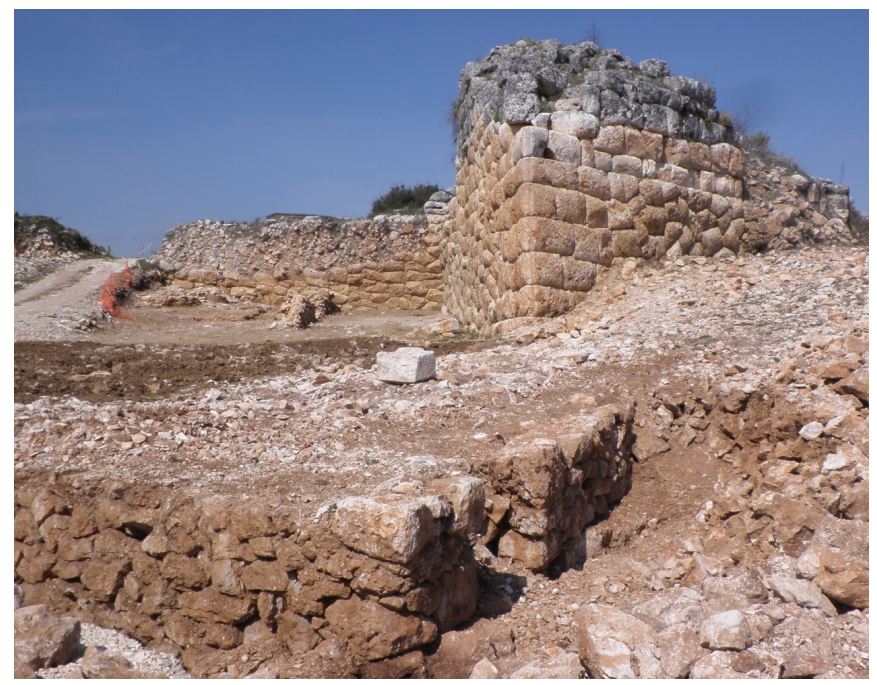

Figure 16. Temporary masonry foundations, adjacent to the edge of the tower.

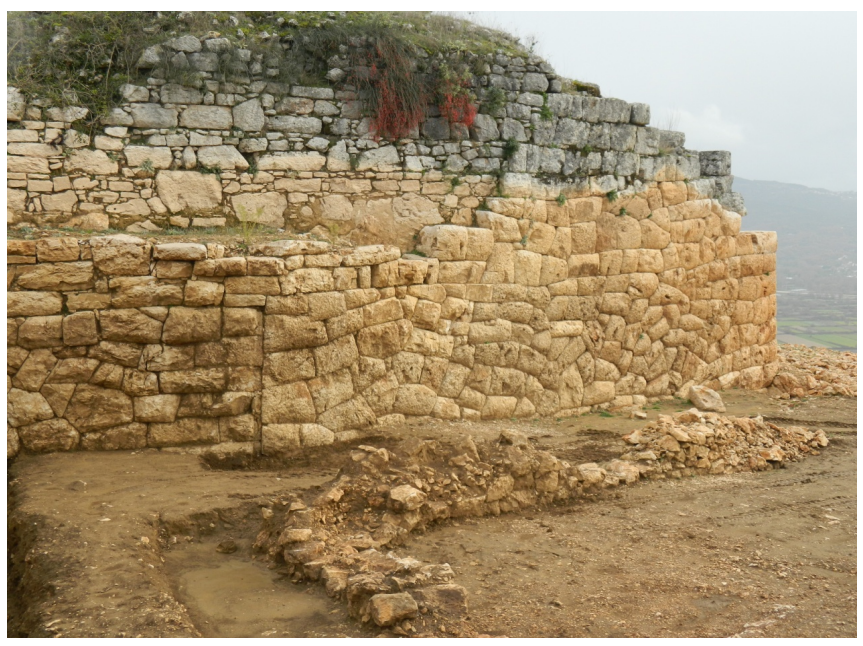

Figure 17. Temporary masonry foundations, adjacent to the edge of the tower.

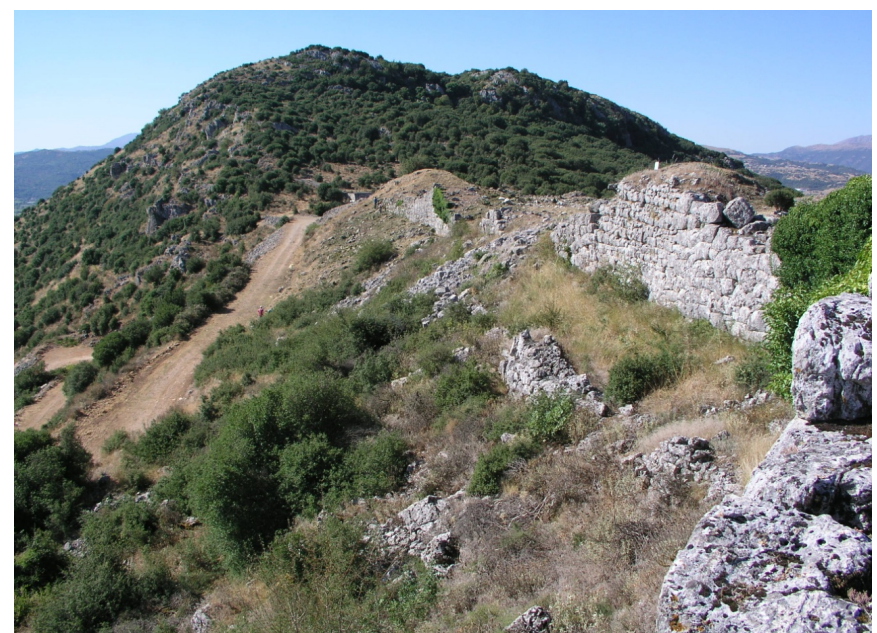

Figure 18. The opposite hill-plausibly the potential camping and attacking point of the enemy army. 


\section{Conclusion}

The archaeological data revealed rational preparation for defense and resistance from the defenders, which included: 1) the addition of the triangle edge to the eastern tower, the blunt surface of which was undoubtedly a difficult task for the besiegers and 2) the construction of additional fortifications, although moderate, outside the tower. Unfortunately, given the lack of epigraphic data, the exact identification the Hellenistic city that had been prepared for defense and siege, and clearly its policy was different from most Hellenistic cities of Epirus during the Third Macedonian War (171 B.C-168 B.C) except the four ones mentioned by Livy (i.e., Passarona, Tekmon, Orraon and Filaki) is a difficult task.

The material remains from Kastritsa depict that the city was prepared for resistance following a strikingly different policy than the unresisting one of Orraon and Fylaki and the loose resist of Passarona, as Livy reports. With the present archaeological data at hand, although by no means conclusive, we argue that the Hellenistic city lying on the hill of Kastritsa might have been Livy's Tekmon and the organized preparation for resistance, the result of strong anti-Roman attitude of its leader Kefalos as Livy mentions. This report provides preliminary evidence of a military conflict in front of the city walls of Kastritsa and attempts to link ancient literature (i.e., Livy) with an ancient city (i.e., Tekmon); however, is limited by the absence of precise dating of the "battle layer" and comparative examples. Future research will prove whether the approach presented above is sealed strongly with other co-finds in the "battle layer" or is just a heuristic interpretation.

\section{Conflicts of Interest}

The authors declare no conflicts of interest regarding the publication of this paper.

\section{References}

Andreou, J. (1997). I topografía tis Amvrakías kai ipoliorkía tou 189 B.C. In Afiéroma ston N. G. L. Hammond. Parártima Makedonikón 7 (pp. 17-36). Thessaloníki.

Baatz, D. (1978). Recent Finds of Ancient Artillery. Britannia, 9, 1-17. https://doi.org/10.2307/525936

Baatz, D. (1982). Hellenistische Katapulte aus Ephyra (Epirus). Mitteilungen des Deutschen Archäologischen Instituts Athenische Abteilung, 97, 211-233.

Baatz, D., \& Feugère, M. (1981). Eléments d'une catapulte trouvée à Lyon. In Gallia (Tome 39, fascicule 2, pp. 201-210). Editions du CNRS.

https://doi.org/10.3406/galia.1981.1830

Cabanes, C., \& Andréou. J. (1985). Le règlement frontalier entre les cités d'Ambacie et de Charadros. Bulletin de Correspondance Hellénique, 109, 520-521. https://doi.org/10.3406/bch.1985.1834

Campbell, D. B. (2011). Ancient Catapults: Some Hypotheses Reexamined. Hesperia, 80, 677-700. https://doi.org/10.2972/hesperia.80.4.0677

Dakaris, S. (1964). Anaskafí eis to nekyomanteíon tou Achérontos. Praktika Archaeologikis Eterias, 53, 50. 
Dausse, M. P. (2007). Les villes molasses: Bilan et hypothèses sur les quatre centres mentionnés par Tite-Live. Épire, Illyrie, Macédoine: Mélanges offerts au Professeur Pierre Cabanes, 2007, 197-233.

Gravani, K., \& Katsikoudis, N. (2019). To nekromanteío tou Achéronta. Protáseis ermineías. In I. Thesprotía (Ed.), Chouliarás, I.P.-PliákouG.TH (pp. 135-160), Ioánnina: Ipurgio Politismou kai Athlitsimou, Ephoria Arhaiotiton Thesprotias.

Hacker, B. C. (1968). Greek Catapults and Catapult Technology: Science, Technology and War in the Ancient World. Technology and Culture, 9, 34-50. https://doi.org/10.2307/3102042

Kappa, H., \& Kontogiorgos, D. (2018). I ochýrosi tis akrópolis tis Kastrítsas: néa dedoména tis érevnas. In Archaiologikó Érgo sti Voreiodytikí Elláda kai ta nisiá tou Ioníou I (pp. 127-134). Athína: Tameio Archaeologikon Poron kai Apallotrioseon.

Karatzeni, V. (2001). Epirus in the Roman Era. In Foundation and Destruction. Nikopolis and Northwestern Greece. In J. Isager (Ed.), The Archaeological Evidence for the City Destructions, the Foundation of Nikopolis and the Synoecism, Monographs of the Danish Institute at Athens (Vol. 3, pp. 163-179). Aarhus: Aarhus University Press.

Livius, T. (1905). The History of Rome (Vol. 6). Translator: Rev. Canon Roberts. Editor: Ernest Rhys. London: J. M. Dent \& Sons, Ltd.

Pliakou, G. (2014). Ellinistikí keramikí apó dimósio ktírio stin akrópoli tou "Megálou Gardikíou”, sto lekanopédio ton Ioannínon. In H’Epistimonikí Synántisi gia tin Ellinistikí keramikí (Ioánnina 5-9 Maïou 2009) (pp. 85-95). Praktiká, Athína: Tameio Archaeologikon Poron kai Apallotrioseon. 